\title{
OPTI MALI SASI PERAN PENGAWASAN ORANG TUA DALAM PELAKSANAAN SEKOLAH ONLINE DI MASA PANDEMI COVID-19
}

\author{
Tsaniya Zahra Yuthika Wardhani' ${ }^{1}$, Hetty Krisnani² \\ 1,2 Universitas Padjadjaran \\ ${ }^{1}$ tsaniyazahraa@yahoo.com, 2 hettykrisnani123@gmail.com
}

\begin{abstract}
ABSTRAK
Pasca mewabahnya Pandemi Covid-19 di Indonesia pada pertengahan maret 2020 lalu, pemerintah pusat maupun daerah dengan sigap mengeluarkan kebijakan dalam dunia pendidikan yaitu meniadakan sementara pembelajaran tatap muka secara langsung dan diganti dengan pembelajaran secara online, baik pada tingkat sekolah dasar dan menengah, maupun tingkat perguruan tinggi. Kebijakan tersebut bertujuan untuk memutus mata rantai penyebaran wabah ini. Ketentuan pembelajaran jarak jauh melalui metode sekolah online yang secara tiba-tiba diterapkan tentu membawa berbagai kendala. Penulisan artikel ini bertujuan untuk mengidentifikasikan pelaksanaan proses pembelajaran jarak jauh melalui metode sekolah online. Penulis menggunakan metode kualitatif deskriptif dengan menggambarkan dan menjelaskan secara komprehensif dan spesifik berkaitan dengan kejadian atau fenomena yang terjadi saat ini, sehingga tujuan sekolah online dapat tercapai dengan optimal. Hasil dari pembahasan ditemukan bahwa dalam pelaksanaannya, konsep sekolah online membawa kendala dan dampak yang begitu signifikan baik bagi anak sebagai peserta didik maupun guru sebagai tenaga pengajar. Kurangnya fasilitas penunjang yang memadai dan keterbatasan pemahaman mengenai akses teknologi dan jaringan internet menjadi kendala utama yang dirasakan oleh kedua belah pihak. Selain itu, ditemukan juga bahwa peran pengawasan dan perhatian orangtua kepada anak dalam proses pembelajaran online ini sangat penting bagi terwujudnya hasil belajar yang optimal. Orangtua harus hadir dalam mengawasi dan memberi perhatian kepada anak baik pada saat sebelum pembelajaran dimulai, saat pembelajaran berlangsung, sampai dengan setelah pembelajaran selesai.
\end{abstract}

Kata kunci: Sekolah Online, Pandemi Covid-19, Pengawasan orangtua.

\section{ABSTRACT}

After the outbreak of the Covid-19 Pandemic in Indonesia in mid-March 2020, the central and regional governments quickly set an order in terms of education that is temporarily eliminating direct face-to-face learning and replaced with online learning, both at elementary and secondary school levels, and at the level of College. This order aims to break the chain of spread of this epidemic. Provisions for distance learning through online school methods that are suddenly applied certainly bring various obstacles. The writing of this article aims to identify the implementation of the distance learning process through online school methods. The author uses descriptive qualitative methods to describe and explain comprehensively and specifically related to events or phenomena that occur at this time, so that the goals of online schools can be achieved optimally. The results of the discussion found that in its implementation, the concept of online schooling brought constraints and significant impacts for both children as students and teachers as teaching staff. Lack of adequate supporting facilities and limited understanding of technology and internet network access are the main obstacles felt by both parties. In addition, it was also found that the role of supervision and attention of parents to children in the online learning process is very important for the realization of optimal learning outcomes. Parents must be present in supervising and paying attention to children both before learning begins, when learning takes place, until after learning is finished.

Keywords: Online Schools, Pandemic Covid-19, Parental supervision. 


\section{PENDAHULUAN}

Penyebaran virus Corona (Covid-19) yang dengan cepat meluas ke seluruh belahan dunia, menimbulkan perubahan pola aktivitas pada seluruh sektor kehidupan manusia pada saat ini. Hal serupa juga terjadi di Negara kita, yakni Indonesia. Menyikapi cepatnya penyebaran virus tersebut, pemerintah dengan sigap mengambil kebijakan di segala bidang termasuk bidang pendidikan di tanah air. Melalui Kementerian Pendidikan dan Kebudayaan (Kemendikbud) Indonesia memberlakukan kebijakan Belajar di Rumah dengan sistem pembelajaran jarak jauh melalui motode sekolah online. Sekolah online ini diberlakukan bagi setiap kalangan pelajar dan mahasiswa di seluruh wilayah Indonesia. Di mana pembelajaran atau perkuliahan secara langsung melalui tatap muka diganti dengan pola pembelajaran dalam jaringan (daring) atau online. Sekolah online ini bertujuan untuk memutus mata rantai penyebaran Covid-19.

Menanggapi hal tersebut, pemerintah pusat hingga daerah memberikan kebijakan untuk meliburkan seluruh lembaga pendidikan. Diharapakan dengan seluruh lembaga pendidikan tidak melaksanakan aktivitas seperti biasanya, maka akan dapat meminimalisir menyebarnya wabah Covid-19 ini. Hal serupa juga sudah dilakukan oleh berbagai negara yang terpapar wabah ini, kebijakan lockdown atau karantina dilakukan sebagai upaya mengurangi interaksi banyak orang yang dapat memberi akses pada penyebaran virus corona. Penyebaran virus corona ini pada awalnya sangat berdampak pada dunia ekonomi yang mulai lesu, tetapi kini dampaknya dirasakan juga oleh dunia pendidikan. Kebijakan yang diambil oleh banyak negara termasuk Indonesia dengan meliburkan seluruh aktivitas pendidikan, membuat pemerintah dan lembaga terkait harus menghadirkan alternatif proses pendidikan bagi peserta didik maupun mahasiswa yang tidak bisa melaksanakan proses pendidikan pada lembaga pendidikan.

Korban akibat wabah Covid-19, tidak hanya pendidikan di tingkat Sekolah Dasar/Madrasah Ibtidaiyah, Sekolah Menengah Pertama/Madrasah Stanawiyah, dan Sekolah Menengah Atas/Madrasah Aliyah, tetapi juga Perguruan Tinggi. Seluruh jenjang pendidikan dari sekolah dasar/ibtidaiyah sampai perguruan tinggi (universitas) baik yang berada dibawah Kementerian Pendidikan dan Kebudayaan RI maupun yang berada dibawah Kementerian Agama RI semuanya memperoleh dampak negatif karena pelajar, siswa dan mahasiswa "dipaksa" belajar dari rumah karena pembelajaran tatap muka ditiadakan untuk mencegah penularan Covid-19. Padahal tidak semua pelajar, siswa dan mahasiswa terbiasa belajar melalui online. Apalagi guru dan dosen masih banyak belum mahir mengajar dengan menggunakan teknologi internet atau media sosial terutama di berbagai daerah.

Pada dasarnya setiap anak memiliki potensi yang tidak terbatas. Tetapi ada beberapa faktor yang dapat mempengaruhi apakah mereka pada akhirnya memenuhi potensi itu. Para ahli percaya bahwa peran orangtua dalam kehidupan anak memiliki dampak yang luas. Keterlibatan orangtua sangat penting bagi anak untuk berprestasi di sekolah. Beberapa orangtua mungkin berpikir bahwa itu adalah peran guru untuk mengajar, bukan peran mereka. Tetapi kepercayaan seperti itu tidak merugikan orangtua dan anak-anak. Anak-anak tidak memulai dan berhenti belajar hanya selama hari sekolah. Mereka selalu terbiasa dengan belajar, di rumah, dengan teman, dan melalui pengaruh lain. Pendidikan merupakan hal terbesar yang selalu diutamakan oleh para orangtua. Saat ini masyarakat semakin menyadari pentingnya memberikan pendidikan yang terbaik kepada anak-anak mereka sejak dini. Untuk itu orang tua memegang peranan yang sangat penting dalam membimbing dan mendampingi anak dalam kehidupan keseharian anak. Sudah merupakan kewajiban para orang tua untuk menciptakan lingkungan yang kondusif sehingga dapat memancing keluar potensi anak, kecerdasan dan rasa percaya diri. Dan tidak lupa memahami tahap perkembangan anak serta kebutuhan pengembangan potensi kecerdasan dari setiap tahap.

Tugas orangtua terutama ibu, saat ini menjadi bertambah berat setelah pemerintah memutuskan penerapan kebijakan proses belajar mengajar yang diubah menjadi online artinya belajar dari rumah selama pandemic Covid-19. Memang dari berbagai Dinas Pendidikan dan Kebudayaan, seperti Dinas Pendidikan dan Kebudayaan Jakarta, terdapat panduan normatif seperti dalam akun Instagram tentang tugas untuk kepala sekolah, guru, orang dan siswa. Misalnya tugas Kepala Sekolah adalah memberikan surat tugas kepada guru serta surat edaran kepada orangtua untuk melakukan kegiatan pembelajaran di rumah, dalam rangka meningkatkan kewaspadaan dan pencegahan penularan virus corona di sekolah. Kepada para 
guru juga ada tugas, misalnya menyiapkan bahan ajar yang akan diunggah kepada siswa, menentukan media belajar seperti grup Whatsapp, Email, Google Clasroom, atau aplikasi media belajar lain sesuai rekomendasi Kemendikbud. Kepada para orang tua juga diminta untuk memastikan siswa melaksanakan kegiatan belajar di rumah masing-masing, membatasi izin kegiatan di luar rumah, berkoordinasi dengan wali kelas, guru atau sekolah, membantu siswa menerapkan pola hidup bersih sehat (PHBS) di rumah dan sebagainya. Kepada para siswa diminta mempelajari bahan atau materi mata pelajaran yang diunggah guru melalui media yang telah disepakati. Kemudian melakukan diskusi dengan guru melalui media online jika masih ada hal yang kurang jelas dari materi yang diberikan.

Namun sebenarnya beban yang cukup berat kini berada dipundak para orang tua. Penyesuaian yang cukup berat justru akan terjadi di rumah, khususnya orangtua dalam mendampingi dan mengawasi anak tatkala mengikuti proses belajar di rumah itu dengan memberikan pengertian bahwa mereka harus tetap belajar seperti biasa. Penulisan artikel ini bertujuan untuk memberikan literarure review yang akan memfokuskan pembahasan kepada konsep pembelajaran jarak jauh melalui metode sekolah online dan peran penting pengawasan orangtua dalam pelaksanaan sekolah online di masa pandemi Covid-19.

\section{METODE PENELITIAN}

Penulisan artikel ini secara keseluruhan menerapkan metode kualitatif deskriptif. Metode penelitian ini telah menjadi metode yang sangat umum untuk melakukan penelitian di banyak disiplin ilmu, termasuk pendidikan, psikologi, ilmu sosial, dan sebagainya. Metode deskriptif pada dasarnya berupaya untuk menggambarkan atau menjelaskan atau menjelaskan tentang suatu gejala sosial. Metode kualitatif memberikan informasi yang mutakhir sehingga bermanfaat bagi perkembangan ilmu pengetahuan serta lebih banyak dapat diterapkan pada berbagai masalah Dengan kata lain tujuan dari metode kualitatif deskriptif ini adalah untuk memberikan kajian yang komprehensif dan spesifik berkaitan dengan kejadian atau fenomena yang terjadi dalam kehidupan sehari-hari atau dari peristiwa spesifik yang dialami oleh individu atau kelompok individu (Sarwono, 2006).

\section{TI NJ AUAN PUSTAKA}

\section{KONSEP DASAR PELAKSANAAN SEKOLAH ONLINE}

Indonesia saat ini tengah dijajah oleh pandemi Covid-19, dimana dunia pendidikan ikut merasakan dampaknya. Diberlakukannya konsep pembelajaran jarak jauh melalui metode sekolah online agar kegiatan berpelajaran tetap berjalan merupakan salah satu upaya menghentikan penyebaran wabah ini (Chick \& Clifton, 2020). Dalam penerapan pembelajaraan jarah jauh ini tentu tidak menjadi masalah bagi Perguruan Tinggi yang sudah biasa menjalani akademiknya melalui daring namun akan sangat dirasakan bagi jenjang pendidikan Sekolah Dasar sampai dengan Perguruan Tinggi tertentu yang belum memiliki akses memadai atau belum terbiasa dengan sistem akademik berbasis daring.

Pembelajaran jarak jauh merupakan pendidikan formal berbasis lembaga, dimana kelompok belajar terpisah dan digunakan sistem komunikasi dalam interaksi. Pembelajaran jarak jauh dalam pelaksanaannya dapat membuat anak sebagai peserta didik memiliki keterampilan serta kesempatan lebih besar dalam berinteraksi (Dede, 1990). Pembelajaran jarak jauh dipilih sebagai sesuatu konsep yang mendukung untuk digunakan dalam masa pandemi, terutama saat Covid-19. Dalam hal ini tentunya teknologi memiliki peran yang sangat penting untuk memfasilitasi dalam interaksi, berkomunikasi serta penyajian agar proses pembelajaran berjalan dengan baik. Oleh karena itu penting sekali memanfaatkan teknologi dengan semaksimal mungkin. Dan peran media pembelajaran sangat dibutuhkan untuk mempermudah komunikasi antara pendidik dengan peserta didik (Borisova, 2016). Namun jika tidak dimanfaatkan dengan baik tentunya hanya akan menimbulkan masalah, terjadi kegagalan dan pembelajaran tidak berjalan dengan baik dan hanya akan menjadi bahan evaluasi dari pembelajaran jarak jauh (Moore \& Dickson-Deane, 2011).

Media pembelajaran merupakan gabungan antara bahan belajar dengan alat belajar dan merupakan bagian dari sumber belajar untuk dijadikan sebagai penyampain pesan dan informasi dalam pembelajaran (Muhson, 2010). Tujuan digunakannya media pembelajaran yang terdiri dari bahan dan alat 
belajar yakni agar pelaksanaan dari suatu pembelajaran bisa dicapai dengan maksimal serta untuk meningkatkan efektivitas hasil pencapaian (Dewi, Murtinugraha, \& Arthur, 2018). Sejalan dengan pemanfatan dan perancangan media pembelajaran dengan baik maka pemahaman murid dalam proses belajar akan dapat diserap dengan baik pula. Beberapa media pembelajaran yang sering digunakan dalam pembelajaran jarak jauh dimasa pandemi ini agar mempermudah jalannya proses pembelajaran. Penggunaan power point sebagai media pembelajaran sudah banyak digunakan dalam proses pembelajaran karena efektif digunakan serta dapat menigkatkan minat belajar (Fitriyani, Tontowi, \& Basri, 2017). Namun pada penggunaannya penyajian materi keterampilan mengajar belum memenuhi konten multimedia sehingga perlu menambahkan konten multimedia agar lebih optimal dalam penggunaannya dan tingkat pemahaman dalam penggunaan dikategorikan cukup (Mawardi \& I riani, 2019).

Beberapa media pembelajaran yang sering digunakan dalam pembelajaran jarak jauh dimasa pandemi ini agar mempermudah jalannya proses pembelajaran. Penggunaan power point sebagai media pembelajaran sudah banyak digunakan dalam proses pembelajaran karena efektif digunakan serta dapat menigkatkan minat belajar. Namun pada penggunaannya penyajian materi keterampilan mengajar belum memenuhi konten multimedia sehingga perlu menambahkan konten multimedia agar lebih optimal dalam penggunaannya dan tingkat pemahaman dalam penggunaan dikategorikan cukup.

Penggunaan virtual learning dalam proses pembelajaran jarak jauh diyakini memberikan lebih kemudahan belajar, dapat berkomunikasi secara langsung sehingga materi mudah untuk diterima. Pengunaan virtual learning dapat digunakan salah satunya dengan aplikasi zoom. Aplikasi ini dilakukan seakan-akan terjadi dalam pembelajaran dalam kelas, penggunaan aplikasi yang mudah digunakan, namun sering belakangan ini terjadi pencurian data pada pengguna sehingga kurang aman untuk digunakan dan penggunaannya membutuhkan koneksi internet yang besar. Di waktu sekarang ini banyak sekali aplikasi yang digunakan seperti dapat menggunakan webex, microsoft dan lainnya agar pengguna merasa aman.

Terdapat beberapa masalah atau kendala yang dihadapi peserta didik pada pelaksanaan pembelajaran jarak jauh ini, seperti biaya, motivasi belajar, layanan, umpan balik, kurangnya pengalaman serta kebiasaan (Attri, 2012). Pembelajaran jarak jauh dinilai tidak lebih baik dari pembelajaran yang dilakukan secara langsung atau tatap muka. Kurangnya interaksi yang efektif, minimnya pengorganisasian merupakan salah satu yang menjadi kendala pembelajaran jarak jauh, pembelajaran jarak jauh yang efektif tentu harus didukung dengan konten yang diberikan, fasilitas koneksi internet serta perhatian dan ketersediaan yang cukup besar. Oleh karenanya penggunaan media pembelajaran dalam penerapannya mempengaruhi pembelajaran dan pemikiran yang sedang terjadi. Penggunaan media pembelajaran yang tidak interaktif, tidak menari akan membuat peserta didik sulit meningkatkan motivasi belajarnya, maka media pembelajaran yang interaktif serta menarik untuk menghasilkan prestasi peserta didik yang baik. Yang menjadi perhatian khusus dalam pelaksanaan pembelajaran jarak jauh, seperti pada daerah terpencil atau daerah yang tidak mendapat koneksi internet dan terbatasnya kepemilikan teknologi pasti menjadi kendala besar karena pendidik serta sekolah tidak memiliki fasilitasserta sarana yang mempuni untuk proses pembelajaran jarak jauh. Maka dari itu penetuan media pembelajaran sangat berpengaruh terhadap pembelajaran.

\section{a) Dampak Sekolah Online Bagi Anak}

Pelaksanaan pembelajaran secara daring dirumah sebagai akibat dari pandemic Covid-19 tentu membawa berbagai dampak dan pengaruh, salah satunya yakni dampak bagi anak sebagai peserta didik. Dampak utama yang secara langsung dirasakan oleh anak adalah berupa tidak tersedianya fasilitas yang memadai dan lengkap guna menunjang proses pembelajaran yang dilakukan secara daring dirumah. Fasilitas ini sangat penting untuk mendukung kelancaran pembelajaran yang dilakukan jarak jauh secara daring. Contohnya fasilitas yang sangat 
dibutuhkan saat ini sebagai media pembelajaran sekolah online yaitu seperti smartphone, laptop, komputer dan jaringan internet yang memadai yang akan memudahkan anak/murid dalam menyimak proses pembelajaran online. Dampak selanjutnya yang juga menjadi kendala pelaksanaan sekolah online yaitu anak dikejutkan dengan konsep dan kebijakan baru yang secara tiba-tiba diterapkan ini tanpa ada persiapan sebelumnya. Sehingga diperlukan adanya suatu penyesuaian atau adaptasi karena harus disadari bahwa pelaksanaan proses pembelajaran ini akan berpengaruh terhadap daya serap anak dalam memahami materi dan tugas yang diberikan. Karena yang telah dilakukan selama ini, sejak awal seorang anak menginjak bangku sekolah, mereka sudah terbiasa dengan proses pembelajaran secara tatap muka disekolah, bertanya dan berinteraksi secara langsung kepada guru maupun teman sebayanya apabila ada suatu materi yang tidak dipahami, berdiskusi secara langsung, serta sepenuhnya berada dalam pengawasan dan perhatian guru di kelas. Maka dari itu, dengan adanya konsep sekolah online sebagai akibat dari pandemic Covid-19 ini, anak menemukan kendala yang cukup berat.

Konsep pembelajaran jarak jauh melalui sekolah online sebagai salah satu upaya penanggulangan penyebaran Covid-19 ini mengharuskan anak menjadi 'melek' teknologi. Mau ataupun tidak mau, siap maupun tidak siap, seorang anak harus mengerti bagaimana menggunakan dan memanfaatkan teknologi sebagai cara agar tetap bisa mendapatkan pendidikan setiap harinya. Untuk anak sebagai peserta didik usia kelas Sekolah Dasar masih sangat dibutuhkan bantuan orangtua untuk mendampingi dan memantau pembelajaran jarak jauh melalui sekolan online di rumah. Minimal untuk membantu mempersiapkan sarana dan prasarana media teknologi baik sebelum dan sesudah pelaksanaan proses pembelajaran online berlangsung, sehingga anak sebagai peserta didik dapat mengikuti pembelajaran online dengan efektif, tepat waktu, dan tidak kesulitan dalam mengakses materi belajar. Dengan demikian dukungan dan kerjasama orangtua demi keberhasilan pembelajaran jarak jauh melalui sekolah online sangat dibutuhkan.

Namun, di sisi lain apabila seorang siswa belajar dengan suatu metode pembelajaran baru, maka ia akan dihadapkan pada berbagai pengalaman belajar untuk menjadi siswa yang lebih berwawasan luas (Zapalska \& Brozik, 2006). Sikap keterbukaan dalam pengalaman belajar akan mempengaruhi niat siswa untuk dapat lebih mudah dalam beradaptasi dan menerima pembelajaran online melalui nilai-nilai yang dirasakan dari pembelajaran online. Khususnya, siswa yang terbuka untuk pengalaman lebih memperhatikan kualitas pembelajaran online. Siswa yang lebih terbuka menghindari stres karena belajar dalam situasi yang tidak mereka kenal. Selain itu, siswa cenderung mengadopsi pembelajaran online ketika mereka merasa pembelajaran online memenuhi kebutuhan emosional dan sosial mereka. Kebutuhan belajar siswa dan lingkungan belajar online adalah sama dan sebangun. Kebiasaan belajar di sekolah terkesan terbatas, sehingga akan memunculkan kebosanan dan kurangnya tantangan bagi siswa. Siswa terkadang menginginkan metode yang baru dan menarik dalam pembelajaran mereka yang selama ini monoton, dan belajar online setidaknya dapat memenuhi kebutuhan akan hal itu. Siswa bekerja pada kecepatan dan tingkat kemampuan mereka sendiri dan menikmati tantangan, kebebasan, dan kemandirian yang dihasilkan dari belajar online.

\section{b) Dampak Sekolah Online Bagi Guru}

Pada dasarnya perlu disadari bahwa tidak semua guru di Indonesia dapat mahir menggunakan teknologi dan akses internet dengan optimal. Masih cukup banyak kategori guru senior yang telah berusia lanjut serta guru-guru yang berada di daerah pelosok wilayah Indonesia yang belum sepenuhnya mampu untuk mengakses perangkat dan fasilitas penunjang pelaksanaan kegiatan belajar secara online. Penetapan kebijakan sekolah online yang diterapkan 
oleh Pemerintah secara mendadak tentu mendesak para guru dengan kategori diatas untuk turut serta tanpa mendapatkan pendampingan dan pelatihan secara maksimal. Dan kompetensi guru dalam menggunakan teknologi akan mempengaruhi kualitas program belajar mengajar oleh karena itu sebelum diadakan program belajar online para guru wajib untuk diberikan pelatihan terlebih dahulu. Fasilitas yang belum dimiliki oleh semua guru juga menjadi kendala utama dalam pelaksanaan sekolah online. Fasilitas ini sangat penting guna memudahkan guru untuk memberikan materi belajar mengajar secara online. Dampak lain yang dirasakan oleh para guru tidak jauh berbeda dengan murid yakni belum terbiasa dengan pola pembelajaran jarak jauh karena selama ini belajar mengajar dilaksanakan secara tatap muka sehingga interaksi dua arah antara guru dan murid dapat lebih efektif, namun dengan adanya metode pembelajaran jarah jauh membuat para guru perlu waktu untuk beradaptasi. Karena perubahan konsep belajar ini akan membawa berpengaruh yang signifikan terhadap kualitas materi yang disampaikan dan hasil belajar. Dampak selanjutnya yang dialami guru yaitu sekolah diliburkan terlalu lama membuat para guru jenuh, guru terbiasa berada di sekolah untuk berinteraksi dengan teman-temannya. Kemudian guru juga akan kehilangan jiwa sosial, jika di sekolah mereka bisa bermain berinteraksi dengan guru-guru lain dan orang murid tetapi kali ini mereka tidak biasa dan hanya sendiri dirumah.

Kendala lain yang mau atau tidak mau dihadapi para guru adalah adanya penambahan biaya pembelian kuota internet. Teknologi online memerlukan koneksi jaringan ke internet dan kuota oleh karena itu tingkat penggunaaan kuota internet akan bertambah dan akan menambah beban pengeluaran guru. Untuk melakukan permbelajaran online selama beberapa bulan tentunya akan diperlukan kuota yang lebih banyak lagi dan secara otomatis akan meningkatkan biaya pembelian kuota internet. Kompetensi guru dalam memanfaatkan teknologi dan menguasai teknologi untuk pembelajaran dituntut untuk meningkat dengan cepat untuk merespon home learning. Komunikasi guru dan sekolah dengan orang tua harus terjalin dengan lancar. Artinya, ada pengeluaran tambahan biaya yang harus dibayar oleh guru baik berupa material maupun nonmaterial. Misalnya pulsa telpon, pulsa untuk akses internet, dan terutama waktu. Salah satu biaya yang otomatis harus dibayar oleh guru adalah guru juga harus memberi technical support pada orangtua apabila terjadi glitches (masalah) dengan baik yang berhubungan dengan teknologi yang langsung digunakan dalam proses pembelajaran maupun setting gawai yang digunakan oleh peserta didik (Abdulhak \& Darmawan, 2005). Jam kerja yang menjadi tidak terbatas karena harus berkomunikasi dan berkoordinasi dengan peserta didik, orang tua, guru lain, dan kepala sekolah. Tidak setiap guru cepat mengadopsi dan belajar teknoloogi, sehingga sebagai koordinator jam kerja tak terbatas di hari kerja. Sabtu dan sampai Minggu malam pun tetap dituntut secara moral dan tanggung jawab untuk mempersiapkan guru-guru yang masih butuh support untuk menjalankan home learning.

Namun disisi lain, tinjauan literatur saat ini telah menemukan bahwa ada banyak penelitian tentang efektivitas teknologi dalam pendidikan online berkaitan dengan penghematan biaya dan efisiensi, bahwa peningkatan kualitas dan efektivitas pendidikan online memerlukan kerangka kerja yang harus diterapkan di sekolah. Kerangka yang diusulkan memberikan panduan praktis kepada para pemangku kepentingan dalam penilaian kualitas pengajaran dan pembelajaran online. Terdapat beberapa faktor yang dapat menciptakan pengalaman belajar yang menarik bagi pembelajar online. Faktor utama adalah sebagai berikut: menciptakan dan memelihara lingkungan belajar yang positif; membangun komunitas belajar; memberikan umpan balik yang konsisten secara tepat waktu; dan menggunakan teknologi yang tepat untuk mengirimkan konten yang tepat . Seiring meningkatnya peluang pembelajaran 
online dalam masyarakat saat ini, pustakawan perlu mempertimbangkan cara-cara tambahan untuk merancang instruksi online secara efektif. Mengembangkan strategi yang diperlukan untuk mengajar dan belajar secara online dengan sukses membutuhkan pemahaman tentang gaya belajar dan bagaimana mereka dapat ditangani dengan baik di lingkungan online. Seperti halnya di kelas tatap muka, penggunaan gaya mengajar tertentu atau serangkaian gaya harus diperluas untuk mengatasi gaya belajar yang berbeda saat mengajar online. Pengajaran dan pembelajaran yang sukses tergantung pada semua peserta yang memiliki sikap yang diperlukan untuk berhasil di lingkungan online. Hal memberikan informasi tentang gaya belajar dan mengajar, dan membahas bagaimana mengajar dengan berbagai gaya belajar dapat dilakukan dengan menggunakan alat dan sumber daya online yang tersedia.

\section{PEMBAHASAN}

\section{PERAN PENTI NG PENGAWASAN ORANGTUA DALAM PELAKSANAAN SEKOLAH ONLINE DI MASA PANDEMI COVID-19}

Dorongan orangtua dan dukungan untuk kegiatan belajar di rumah dikombinasikan dengan keterlibatan guru pada pemberian materi belajar sangat penting untuk keberlangsungan pendidikan anak. Semakin banyak sumber yang menunjukkan bahwa membangun kemitraan yang efektif antara orangtua, keluarga, dan sekolah untuk mendukung pembelajaran anak mengarah pada hasil belajar yang lebih baik. Orangtua adalah pendidik pertama dan berkelanjutan dari anak-anak mereka. Penelitian juga menunjukkan bahwa kualitas guru, termasuk standar dan pelatihan dalam keterlibatan orangtua, penting untuk memfasilitasi keterlibatan orang tua yang efektif. Dianggap luas, keterlibatan orangtua terdiri dari kemitraan antara keluarga, sekolah dan masyarakat, meningkatkan kesadaran orangtua tentang manfaat terlibat dalam pendidikan anak-anak mereka, dan memberikan mereka keterampilan untuk melakukannya. Sebagaimana Muller menyatakan, "Kemitraan keluarga-sekolah dan masyarakat sedang mendefinisikan kembali batas-batas dan fungsi-fungsi pendidikan. Mereka memperbesar kapasitas orang tua dan komunitas; mereka menciptakan kondisi di mana anak-anak belajar lebih efektif. Dengan cara ini mereka mengambil pendidikan di luar gerbang sekolah" (Müller, 2009).

Dampak yang dirasakan oleh orangtua dalam sistem pembelajaran jarak jauh melalui sekolah online juga cukup beragam. Orangtua harus menambah beban pengeluaran untuk memberikan fasilitas yang memadai bagi anak agar dapat mengikuti pembelajaran secara daring. Untuk melaksanakan sekolah online yang sampai saat ini belum dapat diketahui akan berlangsung sampai berapa bulan kedepan, tentunya mengharuskan orangtua untuk menyediakan setidaknya kuota internet yang cukup banyak ataupun dengan berlangganan jaringan WiFi yang tidak murah semata-mata agar proses belajar secara online yang dilakukan oleh anak dapat berlangsung dengan lancar. Dampak selanjutnya yang harus dihadapi oleh orangtua dalam pelaksanaan pembelajaran jarak jauh melalui metode sekolah online ini yaitu berkaitan dengan waktu. Orangtua wajib menyediakan waktu luang yang cukup ekstra agar dapat mendampingi anak dalam melakukan sekolah online. Karena anak belum tentu bisa mengakses dan menyerap materi serta tugas-tugas dari pembelajaran online ini sendiri, sehingga orangtua harus hadir dalam mengawasi dan memberi perhatian kepada anak baik pada saat sebelum pembelajaran dimulai, saat pembelajaran berlangsung, sampai dengan setelah pembelajaran selesai. Agar isi dan materi dari sekolah online tersebut tidak sia-sia. Hal ini tentu saja akan sangat berpengaruh terhadap waktu yang dimiliki orangtua untuk melaksanakan aktivitas pribadinya seperti bekerja, kegiatan rumahtangga dan lain sebagainya.

Konsep pembelajaran jarak jauh melaui metode sekolah online juga 


\begin{tabular}{|c|c|c|c|c|}
\hline $\begin{array}{c}\text { Prosiding Penelitian \& } \\
\begin{array}{c}\text { Pengabdian Kepada } \\
\text { Masyarakat }\end{array}\end{array}$ & $\begin{array}{c}\text { e ISSN : 2581-1126 } \\
\text { p ISSN : 2442-448X }\end{array}$ & Vol 7, No: 1 & Hal: $48-59$ & April 2020 \\
\hline
\end{tabular}

memaksa orangtua untuk dapat menggunakan teknologi. Karena ia akan mengajarkan teknologi tersebut kepada anaknya. Orangtua harus kreatif dan inovatif dalam menyiapkan pelaksanaan sekolah online dan memberikan bimbingan atau tuntunan kepada anak agar dapat memanfaatkan akses teknologi modern dalam proses pembelajaran yang nantinya juga akan meningkatkan kualitas dari anak itu sendiri (Prasojo \& Riyanto, 2011). Orangtua yang mempunyai kendala dengan tuntutan kerjanya ditambah dengan tuntutan untuk mendampingi pembelajaran anak di rumah, sebagian tentu ada yang melampiaskannya hal ini kepada guru. Namun, tidak sedikit pula orangtua yang menjadi sadar akan peran yang selama ini dijalankan oleh guru di sekolah. Mereka menyadari betapa sulitnya mengajar satu atau dua orang anak kandungnya sendiri dirumah, sementara guru harus memberikan perhatian dan bimbingan kepada lebih dari dua puluh anak di sekolah dengan sabar dan telaten. Sehingga proses pembelajaran jarak jauh melalui metode sekolah online ini juga membawa dampak kepada orangtua yang menjadi sangat mengapresiasi kegigihan guru selama ini mengajar anaknya di sekolah. Keterlibatan orangtua (dari berbagai jenis) juga memiliki dampak positif pada banyak indikator prestasi siswa, termasuk antara lain:

- $\quad$ Nilai dan nilai ujian lebih tinggi

- Pendaftaran dalam program tingkat yang lebih tinggi dan kelas lanjutan

- Tingkat drop-out yang lebih rendah

- $\quad$ Tingkat kelulusan yang lebih tinggi

- Kemungkinan besar memulai pendidikan tinggi.

Selain prestasi pendidikan, keterlibatan orangtua pun dikaitkan dengan berbagai indikator perkembangan siswa. Hal ini termasuk antara lain:

- Keterampilan sosial yang lebih baik

- Perilaku yang lebih baik

- $\quad$ Adaptasi yang lebih baik ke sekolah

- Modal sosial meningkat
- Rasa yang lebih besar dari kompetensi pribadi dan kemanjuran untuk belajar

- Keterlibatan yang lebih besar dalam pekerjaan sekolah

- Keyakinan yang lebih kuat akan pentingnya pendidikan.

Pelaksanaan pembelajaran jarak jauh melalui metode sekolah online bisa dilakukan dengan berbagai cara sesuai dengan kreativitas guru atau pendidik masing-masing. Pada tingkat Sekolah Dasar dilakukan dengan menggunakan media WhatsApp di mana anak-anak diberi tugas kemudian tugas yang diberikan dikirim kembali melalui WhatsApp tersebut. Demikian pula untuk laporan pengerjaan tugas dari anak-anak kepada guru. Dengan melalui pembelajaran daring itu guru dapat memantau kegiatan anak di rumah walaupun tidak bisa secara utuh seperti pengawasan ketika di sekolah. Setidaknya dengan adanya pembelajaran daring, anak-anak masih bisa tetap belajar, namun tetap terpantau. Adapun peran orangtua di rumah yaitu mendampingi anak-anak dalam mengerjakan tugas sekolah, sehingga mereka masih dapat belajar di rumah. Kepada para orang tua juga diminta untuk memastikan siswa melaksanakan kegiatan belajar di rumah masing-masing, membatasi izin kegiatan di luar rumah, berkoordinasi dengan wali kelas, guru atau sekolah, membantu siswa menerapkan pola hidup bersih sehat (PHBS) di rumah dan sebagainya (Pujilestari, 2020).

Kegiatan pembelajaran yang dilaksanakan secara daring nyatanya tidak lebih mudah dibandingkan dengan pembelajaran secara tatap muka. Orangtua dituntut untuk mampu berperan sebagai guru bagi anak-anak mereka, dan hal tersebut tidaklah mudah. Orangtua harus belajar kembali tentang materi pelajaran yang tengah dipelajari oleh anak. Hal ini tentunya menjadi tantangan yang tidak akan mudah untuk dilalui mengingat materi pelajaran saat ini jauh berbeda dengan apa yang dipelajari oleh para orangtua kita dahulu. 
Bagi orangtua dengan latar belakang pendidikan yang memadai serta didukung dengan fasilitas atau sarana yang lengkap, mendampingi anak untuk belajar di rumah mungkin tidak akan terlalu berat. Yang diperlukan adalah kesediaan dan kesabaran untuk tetap berada di samping anak-anaknya. Lain halnya dengan orangtua yang tingkat pendidikannya kurang memadai, menjadi guru bagi anak-anak mereka bukanlah perkara mudah. Selain itu keterbatasan akses informasi juga menjadi kendala tersendiri bagi sebagian orangtua dalam membimbing anak-anaknya. Beratnya tantangan dalam mendidik anak sendiri di rumah pada akhirnya membuat sebagian orangtua bereaksi terhadap kebijakan sekolah yang memberikan tugas terlalu banyak kepada anak-anak mereka. Sebagian bahkan melapor kepada pihak Komisi Perlindungan Anak Indonesia (KPAl) karena anak serta orangtua mengalami stress dengan banyaknya tugas yang harus diselesaikan.

Menanggapi hal tersebut, terdapat beberapa alternatif cara yang dapat dilakukan orangtua sebagai bentuk perhatian dan pengawasan kepada anak dalam pelaksanaan sekolah daring ini agar hasil pembelajaran dapat diperoleh secara maksimal dan optimal, yakni:

1. Disiplin. Meskipun anak berada di rumah, orang tua tetap harus memperlakukan kebiasaan saat anaknya bersekolah. Misalnya, anak harus bangun jam 6 pagi, mandi, sarapan, dan bersiap-siap untuk ke sekolah. Setelah itu ikuti jadwal pelajaran seperti di sekolah agar membuat anak tetap disiplin meskipun ada di rumah. Ketika tiba waktunya untuk beristirahat, biarkan anak menghentikan kegiatan belajarnya. Ini penting untuk merelaksasi pikiran dan membuat anak kembali fokus. Demikian juga bila sudah waktunya untuk selesai belajar, hentikan kegiatan belajar.

2. Tepat waktu. Ingatkan anak, meski mereka berada di rumah, bukan berarti mereka bisa bersantai dan bermain sepanjang hari. Pengawasan terhadap pelaksanaan sekolah online dapat dilakukan orangtua dengan memberikan pemahaman dan kesadaran kepada anak bahwa meskipun tidak berangkat sekolah secara efektif seperti biasanya, mereka juga tetap memiliki tanggungjawab kepada tugas-tugas yang telah diberikan oleh guru melalui sekolah online tersebut. Agar anak tidak kebingungan, orangtua dapat membantu dengan membuat daftar tugas-tugas yang harus diselesaikan beserta dengan tenggat waktu (deadline) yang diberikan. Sehingga orangtua tetap dapat mengawasi dan memastikan anak menyelesaikan semua tugas dengan baik dan tepat waktu.

3. Selalu mendampingi anak dalam belajar. Pendampingan orangtua dalam rangka tetap mengawasi pelaksanaan sekolah online yang dilakukan oleh anak harus diperhatikan beik-baik. Orangtuan harus senantiasa mendampingi anak pada saat sebelum pelaksanaan jam sekolah online dimulai, pada saat sekolah online berlangsung, sampai dengan setelah pelaksanaan sekolah onile berakhir. Hal ini menjadi penting agar anak tidak lupa dengan jadwal sekolah onlinenya dan memastikan bahwa materi yang disampaikan pada saat sekolah berlangsung dapat diserap dan dipahami dengan baik oleh anak. Sehingga pelaksanaan sekolah online tidak menjadi sia-sia. Dalam hal ini apabila jadwal bekerja atau kepentingan lain orangtua berbenturan dengan jam sekolah online anak, maka orangtua dapat mencoba mendatangkan seorang guru les privat ke rumah untuk menggantikannya agar anak tetap berada dalam pengawasan dan tidak ketinggalan pelajaran.

4. Apabila menemui kesulitan, segera konfirmasi kepada guru yang bersangkutan. Orangtua harus selalu menjaga hubungan dengan guru pada proses pelaksanaan pembelajaran jarak jauh ini. Dengan begitu, koordinasi antara guru dan orangtua akan selalu terjalin. Hal ini 
sangat penting untuk menghindari adanya misinterpretasi maupun kesalahpahaman dalam upaya memberikan pendidikan yang terbaik bagi anak. Apabila ada materi yang sulit dipahami oleh orangtua, maka tidakperlu segan untuk segera menanyakan hal tersebut kepada guru yang bersangkutan. Karena dalam perlaksanaan pembelajaran jarak jauh melalui metode sekolah online ini, pemahaman anak dalam menguasai materi sangat dipengaruhi oleh bimbingan orangtua.

5. Evaluasi. Evaluasi penting dilakukan untuk mengetahui apakah kegiatan belajar di rumah berjalan sesuai jadwal. Jika anak terlambat dalam menyelesaikan tugas, cari penyebabnya. Diskusikan dengan anak apa kesulitannya dan apakah anak memiliki solusi untuk mengatasi masalah tersebut.

Hal seperti itulah yang perlu dikomunikasikan dengan orang tua siswa. Para orang tua siswa perlu memahami bahwa meski di rumah, anak mereka tetaplah harus konsentrasi pada proses pembelajaran yang tengah berlangsung. Di sinilah dukungan dan pengertian para orang tua sangat dibutuhkan. Dari sini juga akan diketahui bagaimana seharusnya orang tua memberikan pendidikan kepada anak sekaligus memahami apa saja yang menjadi tugas para guru. Karena itu, orang tua juga perlu mendampingi bagaimana anakanak mereka dalam belajar (Praherdhiono, 2020).

Orang tua bukanlah sosok yang hanya berfungsi sebagai pemenuh kebutuhan material anak. Kebutuhan immaterial juga harus mendapatkan porsi yang sama, bahkan lebih. Sebab, kesibukan dan kepadatan urusan orang tua bisa menjadi bumerang ketika tidak diseimbangkan secara baik dalam kehidupan keluarga. Tanpa pendampingan yang bagus dari orang tua, maka hasil pendidikan dari bangku sekolah tidak akan berbekas dan bermakna dalam kemasyarakatan. Sekal lagi, pengawasan dan pengendalian anak usia sekolah sangatlah membutuhkan peran orang tua. Sebab, kemampuan akademis yang mencakup seluruh aspek karakter bahkan jiwa dan raga, tidaklah semata-mata tanggung jawab sekolah (guru). Dan ini menjadi kunci bagi keberhasilan peserta didik menjadi SDM unggul.

\section{PENUTUP}

\section{A. Kesimpulan}

Sebagai bagian dari upaya menghentikan penyebaran wabah Covid-19, pemerintah telah mengalihkan kegiatan pembelajaran dari sekolah ke rumah masingmasing siswa. Agar tak disalahartikan sebagai hari libur, siswa pun diberi tugas-tugas pembelajaran agar mereka tetap dalam suasana belajar. Karena itu, para guru diwajibkan mendesain sedemikan rupa tugastugas bagi peserta didik selama di rumah. Untuk itu, komunikasi merupakan kunci yang sangat penting dilakukan oleh pihak sekolah (guru) dan orangtua agar proses sekolah online ini tetap terlaksana secara intens dengan hasil yang tak terpaut jauh dengan pembelajaran tatap muka (di kelas). Selain itu, guru juga harus membawa budaya belajar di sekolah ke dalam rumah (ruang keluarga) para peserta didik. Artinya, dengan berbagai tugas yang disiapkan itu, para guru harus mengondisikan para orang tua siswa seperti halnya di sekolah. Jika ini terkondisikan secara baik, akan membawa peserta didik ke dalam suasana pembelajaran di lingkungan sekolah. Penting bagi orang tua untuk menjadi roda kemudi pada kendaraan pembelajaran, memberikan bimbingan dan informasi di sepanjang perjalanan, sehingga anak-anak mereka tetap berada di jalur dan tidak terganggu atau dihalangi untuk mencapai potensi akademik mereka.

\section{B. Saran}

Dari proses pembelajaran jarak jauh melalui metode sekolah online sebagai dampak dari pandemi Covid-19 ini diharapkan orangtua memahami betapa sesungguhnya dukungan, pengawasan dan peran mereka sangat sangat dibutuhkan anak-anak dalam proses pembelajaran setiap hari. Kondisi darurat yang menjadi seperti "gerakan serentak" ini pun diharapkan akan menyadarkan orangtua akan perannya dalam mendampingi, membimbing, dan 
mengarahkan anak-anak mereka dalam penyelesaian proses pembelajaran. Mereka juga harus mengenal lebih dekat lagi sikap dan karakter anak mereka. Masih banyak lagi sifat karakter anak yang mungkin belum diketehui orangtua kemudian akan tampak pada saat pengerjaan tugas tersebut. Dari kondisi ini, diharapkan akan dipahami bersama pentingnya pendidikan diawali dari keluarga sebagai tempat pertama dalam pembentukan karakter anak.

\section{DAFTAR PUSTAKA}

\section{Buku}

Abdulhak, Ishak, and Deni. Darmawan. 2005. Teknologi Pendidikan. Bandung: PT. Remaja Rosdakarya Offset.

Müller, A. 2009. Framing Childhood in EighteenthCentury English Periodicals and Prints, 1689-1789. United Kingdom: Ashgate Publishing, Ltd.

Praherdhiono, Henry. 2020. Implementasi Pembelajaran Di Era Dan Pasca Pandemi Covid-19. Malang: CV. Seribu Bintang.

Prasojo, Lantip Diat, and Riyanto. 2011. Teknologi Informasi Pendidikan. Yogyakarta: Gava Media.

Sarwono, Jonathan. 2006. Metode Penelitian Kuantiatif Dan Kualitatif. Yogyakarta: Graha IImu.

\section{J urnal I Imiah}

Attri, A. K. 2012. "Distance Education: Problems and Solutions." International Journal of Behavioral Social and Movement Sciences 1(4): 42-58.

Borisova, O. V. 2016. "Problem of Using Innovative Teaching Methods for Distance Learning Students. International Electronic." Journal of Mathematics Education 11(5): 117584.

Chick, and G. Clifton. 2020. "Using Technology to Maintain the Education of Residents During the COVID-19 Pandemic." Journal of Surgical Education 1(1): 1-4.

Dede, C. J. 1990. "The Evolution of Distance Learning: Technology-Mediated Interactive Learning." Journal of research on Computing in Education 22(3): 247-64.

Dewi, N., Murtinugraha, and R. Arthur. 2018. “Pengembangan Media Pembelajaran Interaktif Pada Mata Kuliah Teori Dan Praktik Plambing." Jurnal PenSil UNJ 7(2): 25-34.

Fitriyani, D., Tontowi, and Basri. 2017. "Pengaruh Media Pembelajaran Power Point Terhadap Minat Belajar Sejarah Siswa." PESAGI (Jurnal Pendidikan dan Penelitian Sejarah) 5(8): 1-12.

Mawardi, and Tuti Iriani. 2019. "Pengembangan Media Pembelajaran Berbasis Multimedia Pada Mata Kuliah Kompetensi Pembelajaran Pokok Materi Keterampilan Dasar Mengajar." Jurnal Pendidikan Teknik Sipil 8(1): 24-30.

Moore, J. L., and Dickson-Deane. 2011. “ELearning, Online Learning, and Distance Learning Environments: Are They the Same?" The Internet and Higher Education 14(2): 129-35.

Muhson, A. 2010. "Pengembangan Media Pembelajaran Berbasis Teknologi Informasi." Jurnal Pendidikan Akuntansi Indonesia 8(2): 1-10.

Pujilestari, Y. 2020. “Dampak Positif Pembelajaran Online Dalam Sistem Pendidikan Indonesia Pasca Pandemi Covid-19." ADALAH: Buletin Hukum dan Keadilan 4(1): 49-56.

Zapalska, A, and D Brozik. 2006. "Learning Styles and Online Education." Campus-Wide Information Systems 23(5): 325-35.

\section{Sumber Pustaka Website dan Portal Berita Online}

Arga Sumantri. 2020. Metamorfosis Dunia Pendidikan di Masa Pandemi Covid19, dikutip

dari https://w ww. medcom.id/pendidikan/inspirasipendidikan/J KRGWI5N-metamorfosisdunia-pendidikan-di-masa-pandemicovid-19 (diakses pada 5 Mei 2020)

Suharwoto, Gogot. 2020. Pembelajaran Online di Tengah Pandemi Covid-19, dikutip dari https://www.timesindonesia.co.id/re 
ad/news/261667/pembelajaranonline-di-tengah-pandemi-covid19tantangan-yang-mendewasakan (diakses pada 4 Mei 2020).

Wibowo, Agung. 2020. Belajar Tetap Kreatif Saat Pandemi Covid-19, dikutip dari https://mediaindonesia.com/rea d/detail/309520-belajar-tetap-kreatifsaat-pandemi-covid-19 (diakses pada 5 Mei 2020). 